Alexander Zorin, Alla Sizova

\title{
On the History of the Formation and Processing of the Collection of the Tibetan Texts from Khara-Khoto Kept at the IOM, RAS*
}

Abstract: The Tibetan manuscripts and block prints from Khara-Khoto that were passed to the Asiatic Museum with other texts brought by P.K. Kozlov from his Mongolia and Sichuan Expedition have been insufficiently studied. Their processing was initiated in the second half of the 1960s and continued in the Post-Soviet period. The collection of the Tibetan Texts from Khara-Khoto, according to our analysis, included a number of documents from other sources. Trying to understand why it took place, we looked for and found some archival documents that shed light on the history of the formation of this collection and, simultaneously, helped to clarify some general issues concerning the fate of texts brought by P.K. Kozlov from Khara-Khoto. This paper presents the results of our study of the documents found in the St. Petersburg Branch of the Archives of the Russian Academy of Sciences, the Archives of the IOM, RAS, the Russian Ethnographic Museum and the Russian Geographic Society. The description of the events is divided into two parts: the first one reconstructs the chronology of the process of transferring manuscripts and block prints of P.K. Kozlov's Expedition to the Asiatic Museum; the second one deals with the history of the processing of the Tibetan texts from KharaKhoto starting from the 1920 s and up to present, when the contents of the collection have been critically revised. The table that reflects the current state of the Collection of the Tibetan Texts from Khara-Khoto kept at the IOM, RAS is provided in the appendix.

Key words: Khara-Khoto, Tibetan manuscripts and block prints, P.K. Kozlov, S.F. Oldenburg, Russian Geographic Society, Russian Museum, Asiatic Museum, processing of manuscripts

(C) Alexander Valerievich Zorin, Institute of Oriental Manuscripts, Russian Academy of Sciences

(C) Alla Alekseevna Sizova, Institute of Oriental Manuscripts, Russian Academy of Sciences

* The study was supported by the Russian Foundation for Basic Research, Project No. 1406-00460, "The Compilation of the Catalogue of the Tibetan texts from Khara-Khoto preserved at the Institute of Oriental Manuscripts, RAS". 
The history of Tangut studies started with the discovery of Khara-Khoto by Russian travelers Ts.G. Badmazhapov (1879-1937) and P.K. Kozlov (1863-1935) at the beginning of the 20th c. ${ }^{1}$ The latter made the first excavations of the site and found a cache of ancient texts and Buddhist artefacts immured in the so-called "Famous" suburgan. The bulk of them were brought to St. Petersburg and are kept now at the IOM, RAS and the State Hermitage Museum. ${ }^{2}$

Tangut and Chinese texts from Khara-Khoto have been studied successfully by Russian and foreign scholars, and several catalogues and facsimile editions of many of them were published. ${ }^{3}$ The Tibetan part of Kozlov's collection, by contrast, remains largely unknown for the academia. Formed as a separate unit of the Institute's manuscripts gathering in 1967, it was first widely introduced by M.I. Vorobyova-Desyatovskaya in her brief English survey of the ancient Tibetan manuscripts kept in the IOM, RAS (formerly the St. Petersburg Branch of the Institute of Oriental Studies). ${ }^{4}$ An introductory article by K.M. Bogdanov can be mentioned, too, ${ }^{5}$ while the very first attempt at cataloguing this collection, made by G.A. Leonov in his graduation thesis supervised by B.I. Kuznetsov (1931-1985), ${ }^{6}$ was never published and is available only as an archival document in the IOM, RAS. This currently outdated catalogue dealt with the 70 items that had been numbered by A.S. Martynov (1933-2013) in the inventory book by the end of the 1960s. Since then, the number of items of the collection has significantly increased.

Meanwhile, the interest of the academia in the actual contents of this collection is rather high. It suffices to mention that one of the most famous Tibetan texts kept at the IOM, namely XT-67, belongs to it. This item seems to be one of the earliest dated blockprints in Tibetan; being preserved only

\footnotetext{
${ }^{1}$ KYCHANOV 2008, 130-131.

${ }^{2}$ Sir Marc Aurel Stein (1862-1943) who visited Khara-Khoto after P.K. Kozlov also found a number of texts there. The Tibetan ones kept at the British Museum were catalogued by the Japanese researchers Ts. Takeuchi and M. Iuchi (TAKEUCHI and IUCHI 2016).

Another collection of Tibetan documents from Khara-Khoto preserved at the Institute of Archeology of Inner Mongolia was introduced in the Institute's combined catalogue of the documents written in languages of the national minorities of China (TALA et al. 2013). A special study of three documents from this collection was carried out in Japan (YosHIDA and CHIMEdDORJ 2008, no. 103-105).

${ }^{3}$ Gorbacheva and Kychanov 1963; MEN'shikov 1984; ECANG HeISHUICHENG WENXIAN 1996-2018; KYCHANOV 1999.

${ }^{4}$ Vorobyova-DesyatovsKaya 1995.

${ }^{5}$ BogdanOV 2010.

${ }^{6}$ LEONOV 1970.
} 
partially, it has very close Chinese and Tangut equivalents that allow us to date it around 1149 .

Another important text from Khara-Khoto, the scroll that contains a collection of tantric texts on the cults of Mahākāla, Viṣṇu Narasinhha, Vajrapāṇi and the eight Nāga Kings, was included mistakenly in the collection of the Tibetan texts from Dunhuang. ${ }^{8}$ At the same time, some manuscripts from Dunhuang were detected among the Tibetan texts from Khara-Khoto. ${ }^{9}$ Moreover, when we started our project aimed at the thorough cataloguing of the Tibetan texts from Khara-Khoto, ${ }^{10}$ we realized very soon that about one third of the entire collection could not be originated from this site. We had to try to understand why and how this mixture took place. Luckily enough, a series of documents found in several archives in St. Petersburg allowed us to reconstruct basically the course of events, although some important details are still not entirely clear. ${ }^{11}$ This reconstruction is presented below, being divided into two stages: the first one relates to the transfer of entire Kozlov's collection to the Asiatic Museum (AM) while the second one to the subsequent processing of its Tibetan part.

${ }^{7}$ There are several papers on XT-67 (SIRAI 2004; SHI 2005; DUAN 2010; etc.); the publication by Shen Weirong (SHEN 2010) is of particular importance as he was first to indicate the exact Chinese equivalent for the Tibetan text. We need to state, however, that his characteristic of Lev Men'shikov's catalogue of the Chinese mansucripts from Khara-Khoto is unfair and not correct: As a piece of sinological work, this catalogue is certainly excellent in its own way. However, the author was not able to convey the full value of these texts for Buddhist studies. He did not pay enough attention to a great number of manuscripts with tantric Buddhist content. Instead he relegated all of them to the amorphous category of "indigenous works" (SHEN 2010, 343). Everyone who can read Russian will see that Men'shikov did pay attention to such manuscripts and described them with many details in a special chapter called The Tantric Texts (gāthā, dhāranī) and some other chapters, too. The comparison of three versions of the block print is an important task that will be hopefully performed in the near future. At present collated Tangut, Chinese and Tibetan versions of Ușṇ̄ṣa Vijaya Dhāraṇī Sūtra, the second part of the edition in question, are available in the paper by Duan Yuquan (DuAN 2010). The study of Tangut and Chinese versions of the third part, namely a postscript (后序) written by the emperor Renzong 仁宗 (reigned 1139-1193), along with the abovementioned second one were published by Lin Ying-chin (LiN 2011).

${ }^{8}$ ZORIN 2015.

${ }^{9}$ E.g. TAKEUCHI 1995.

${ }^{10}$ Besides the authors of this paper the project team includes A.A. Turanskaya.

${ }^{11}$ The Russian version of our paper (ZORIN and SizOva 2019) contains an appendix with full texts of thirteen documents. All the essential quotations from them were translated by ourselves to be presented in this English paper but any interested reader is encouraged to check their full texts as well. 


\section{Transfer of the texts to the Asiatic Museum}

It is well known that in the spring of 1908 some manuscripts were discovered during the first excavations at Khara-Khoto and Kozlov sent them to St. Petersburg. On October 15 (28) a special meeting of the Imperial Russian Geographic Society (IRGS) was held to discuss this finding and Kozlov was invoked to make new excavations. He returned to Khara-Khoto at the end of May 1909 and found the main textual and artistic treasures of the "dead city" in a suburgan situated at some distance from its walls. The excavations were completed on June 7 (20). ${ }^{12}$

In a letter to the Academy of Sciences sent from Irkutsk on August 27, 1909, Kozlov notified that the objects found by the Mongolian-Sichuan expedition had been dispatched by him to St. Petersburg and would arrive there in September. ${ }^{13}$ In St. Petersburg they were temporarily placed in the Building of the IRGS, and the first exhibition of finds from Khara-Khoto was held there in January and February 1910. During this initial period A.I. Ivanov (1877-1937) and V.L. Kotvich (1872-1944) sorted out a number of texts. ${ }^{14}$ The further destiny of the collections, including books, was yet to be settled, according to Kozlov's letter to the Executive Secretary of the Imperial Academy of Sciences (IAS) S.F. Oldenburg on January 16, 1910: "It is not decided so far where the Kara-Khoto [things] will be taken to. I personally tend to prefer the Academy's [Museum] Asiatic Museum. I hope you think the same way, don't you?". ${ }^{15}$

However, the Khara-Khoto texts were moved first to the Ethnographic Department of the Russian Museum (EDRM; later transformed into a separate institution which is called now the Russian Museum of Ethnography). This decision was made by the Emperor Nicholas II as we learn from a letter of notification sent to the EDRM on March 4, $1910 .{ }^{16}$ The situation was

${ }^{12}$ KYCHANOV 2008, 131-132.

${ }^{13}$ SPbB ARAS, coll. 152, inv. 1, item 50, f. 100.

${ }^{14}$ The contribution of both scholars to the study of Kozlov's collection is summarazed in (KyCHANOV 2008, 133-135). V.L. Kotvich made a brief description of a few Mongolian materials (Kozlov 1923, 561-565). A.A. Dostoevsky in one of his letters to Kozlov mentions some details on their work: "After some manuscripts are sorted out they are placed into a special closet in the warehouse. They say a lot of interesting things. I have seen Kotvich, perhaps 3 times, seated at the Society's" (November 8, 1909) (Archive of the RGS: coll. 18, inv. 3, item 216, f. 28-29).

${ }^{15}$ Kozlov 1963, 454-455.

${ }^{16}$ ARME, coll. 1, inv. 2, item 337, f. 2. Other letter (f. 3-4) mentions also an attempt of F.W. Radloff (1837-1918) to get the Kozlov's collections into the possession of the Russian Committee for the study of Central and East Asia that he headed. 
characterized by Kozlov in his letter to A.A. Dostoevsky: $:^{17}$ "The exhibition of the collections of the Mongolian-Sichuan expedition is closed. It is going to be dismantled. I ask you, as the secretary of the Geographical Society, to proceed basically as follows: 1) The entire Khara-Khoto collection is to be passed to the Museum of the Emperor Alexander III, with the exception of two Burkhans...". ${ }^{18}$ The transfer obviously took some time and was not completed by April 2, 1910, when Dostoevsky complained to Kozlov: "Of course, the Museum has not sorted out anything in the collections nor even accepted them officially". ${ }^{19}$

Soon after the EDRM did receive the Khara-Khoto findings its authorities announced their willingness to pass all the texts to the Asiatic Museum. On June 12, 1910, the Deputy Director of the Museum Count Dmitry I. Tolstoy (1860-1941) wrote to the IRGS: "Among the materials acquired by the Museum there is a gigantic number of manuscripts that, according to the unanimous opinion of the members of the Council of the Ethnographic Department, will be much more accessible for research if they are transferred to the institution that is specifically aimed to preserve such documents, namely the Asiatic Museum". ${ }^{20}$ Before this idea was declared, N.M. Mogilyansky ${ }^{21}$ had contacted S.F. Oldenburg and asked him to "prepare the ground for that the Council of the Imperial Geographical Society would not obstruct the EDRM's request concerning the permission to transfer the above-mentioned Khara-Khoto manuscripts". ${ }^{22}$ S.F. Oldenburg promised to promote this undertaking. ${ }^{23}$

On July 14, 1910, the Council of the IRGS announced that it did not see "any obstacles for the transfer of the above-mentioned documents to the

\footnotetext{
${ }^{17}$ Andrei Andreevich Dostoevsky (1863-1933), a nephew of the famous writer, was the IRGS Secretary for twelve years, from 1903.

${ }^{18}$ Kozlov 1963, 455-456. Before the revolution, the official name of the Russian Museum was the Russian Museum of His Imperial Majesty Alexander III.

${ }^{19}$ Archive of the RGS, coll. 18, inv. 3, item 216, f. 34-35.

${ }^{20}$ ARME: coll. 1, inv. 2, item 337, f. 15.

${ }^{21}$ Nikolai Mikhailovich Mogilyansky (1873-1933), an ethnographer and anthropologist, was the Head of the EDRM from 1910 to 1918.

${ }^{22}$ SPbB ARAS, coll. 208, inv. 3, item 396, f. 2. Rough copy is kept at the ARME, coll. 1, inv. 2 , item 337 , f. 13.

${ }^{23}$ ARME, coll. 1, inv. 2, item 337, f. 14. It is worth noting that a year earlier, on February 27, 1910, N.M. Mogilyansky also asked S.F. Oldenburg for advice on the "collections of P.K. Kozlov brought from Khara-Khoto and transmitted by a decree of the Council of the IRGS to the Museum of Alexander III" (SPbB ARAS: coll. 208, inv. 3, item 396, f. 1). The details of this meeting, if it ever took place, are unknown to us.
} 
Asiatic Museum and the [Russian] Museum should apply for the highest permission on that matter". ${ }^{24}$ This "highest permission" was given on March 5, 1911 when Nicholas II visited the Russian Museum. ${ }^{25}$ This issue was discussed at the meeting of the Historical and Philological Department of the IAS on March 30, 1911. Carl Salemann (1850-1916), the Director of the AM, was asked to "get in touch with the curator of the Ethnographic Department of the [Russiam] Museum B.F. Adler" ${ }^{26}$ to discuss the details of the transfer.

Thus, we can be sure that Kozlov's materials could not be received by AM in June 1910, as was commonly assumed. ${ }^{27}$ Luckily enough, the exact date of the transfer, April 20, 1911, turned out to be recorded in a note written by Carl Salemann. ${ }^{28}$ This valuable archival document presents also a rough list of Khara-Khoto manuscript materials: the "chest No. 1 of the Russian Museum" contained "Sinica \& Tangutica, Tg. - 7 packs, Mongolica -1 , assignation -1 pack, Tibetan books, Sinica -3 packs". We can

\footnotetext{
${ }^{24}$ ARME, coll. 1, inv. 2, item 337, f. 18.

${ }^{25}$ It is quite possible that S.F. Oldenburg took part in this event, too, because N.M. Mogilyansky asked him about it in a letter dated January 2, 1911: "The second thing that is not less important - I would like to ask you, in case the Emperor will visit the Museum after January 15 , to give Him the explanations about Khara-Khoto. It is necessary now to complete preparation of the remaining material for the exhibition in the nearest future and I kindly ask you to come to the Museum one of these days and instruct A.A. Miller on this matter" (SPbB ARAS, coll. 208, inv. 3, item 396, f. 3-3 verso).

The letter mentions an archeologist Alexander Miller (1875-1835) who worked at the Russian Museum from 1907 and headed it from 1919 to 1921.

${ }^{26}$ Bulletin 1911. Bruno Friedrichovich Adler (1874-1942), a museum worker and ethnographer, worked at the EDRM in 1910-1911.

${ }^{27}$ KYCHANOV 2008, 133. P.K. Kozlov in his own book on Khara-Khoto's discovery rendered the sequence of events in a slightly abridged form: "In the autumn of 1909 all the finds of the Mongolian-Sichuan expedition were taken to St. Petersburg, to the premises of the Geographical Society. Soon, most of the collections from Khara-Khoto were moved to the Ethnographic Department of the Russian Museum, while the smaller part - books and manuscripts - to the Asiatic Museum of the Russian Academy of Sciences" (KozLOV 1923, 560).

T.I. Iusupova published an excerpt of Kozlov's letter to his wife E.V. Pushkareva where he described the visit of Nicholas II to the exhibition of Khara-Khoto collections at the EDRM on March 5, 1911 and mentioned that the Emperor gave the permission for the transfer of the manuscripts to the AM (IUSUPOVA 2012, 486). As far as we know, T.I. Iusupova's brief comment on this matter was the only correct indication upon the dating of the transfer of the manuscript collection to the AM made so far in academic literature.

${ }^{28}$ ARME, coll. 1, inv. 2, item 337, f. 25.
} 
see from the list that some of the Tibetan texts were already sorted out at early stages. ${ }^{29}$

On April 30, 1911 S.F. Oldenburg officially thanked the Russian Museum on behalf of the IAS "for the transfer of all the manuscript materials to the Asiatic Museum of the Academy". ${ }^{30}$

Although in December 1913, twenty-one more Tibetan books claimed to belong to "the Khara-Khoto collection of the Colonel P.K. Kozlov" were passed to the AM from the EDRM, ${ }^{31}$ they have no relation to Khara-Khoto being rather standard pothi books produced no earlier than in the 18th $\mathrm{c}$. They were probably acquired by Kozlov from different sources during his expedition.

However, a few samples of Tibetan texts from Khara-Khoto remained in the EDRM and, in the early Soviet time, found their way to the State Hermitage Museum along with the numerous Tangut artefacts. In 1936, the academic secretary of the AM's reincarnation, the Institute of Oriental Studies (IOS), the USSR Academy of Sciences, S.N. Muratov (1919-1994) applied to the authorities of the State Hermitage with a proposal to exchange two leaves with images of deities of the planets from the Institute's collection for fragments of Tibetan texts kept at the Hermitage. ${ }^{32}$ We did not find any documents confirming the implementation of this proposal and, since the IOM Tangut collection still has two images of planets (inv. No. 8367) while the State Hermitage Museum still has several fragments of Tibetan texts, this exchange obviously did not take place. ${ }^{33}$

\footnotetext{
${ }^{29}$ While the exhibition of the Mongolo-Sichuan expedition's finds was held at the IRGS in January and February 1910, the eminent St. Petersburg photographer Carl Oswald Bulla (1855-1929) took some pictures of the exhibits. One of them depicts Tangut manuscripts piled up in a display case. In the lower right corner of the display case there is a vertically positioned folio of a book with some Tibetan text. The text and the sheet itself are quite illegible on the available prints (IUSUPOva 2008, 125; Kozlov 2015; Archive of RGS, coll. 17, inv. 7, item 1231). The doubtless identification of the text as Tibetan is based upon an imprint made for us from the negative on glass kept at the Central State Archive of Film, Photo-, and Phonographic Documents in St. Petersburg (call number Д 15832).

${ }^{30}$ ARME, coll. 1, inv. 2, item 337, f. 23.

${ }^{31}$ See N.M. Mogilyansky's letter about the transfer of these books dated December 20, 1913 (SPbB ARAS, coll. 152, inv. 1, item 54, f. 130), and their list (SPbB ARAS, coll. 152, inv. 1 , item 55, f. 121).

${ }^{32}$ The letter dated November 13, 1936 (SPbB ARAS, coll. 152, inv. 1a, item 480, f. 49).

${ }^{33}$ We are most grateful to K.F. Samosyuk, the curator of the collection of Chinese paintings, monuments of art and material culture from the Khara-Khoto, Kucha and Karashar oases at the State Hermitage Museum, for the consultation on this matter.
} 


\section{Processing Tibetan texts from Khara-Khoto}

The World War I, to say nothing of the civil war in Russia, produced a lot of obstacles for the scholarly work. In September 1917, when the German occupation of Petrograd seemed absolutely real the Academy of Sciences decided to evacuate most valuable parts of its collections, including those from the AM, to Saratov University and the Moscow Historical Museum. In early October 1917, gold coins from the AM's rich numismatic collection, were transported to the latter. ${ }^{34}$ From a Soviet book on the history of the Academy's Library we learnt that some books from the AM had been packed and transported to Saratov where they had been "kept unpacked at the University for 3 years... In 1920 the first portion returned to Petrograd, all other manuscripts were transferred from Saratov in 1921". ${ }^{35}$ Surprisingly enough, we managed to learn more about the contents of the cases from an archival document entitled "Inventory of the manuscripts of the Asiatic Museum of the Russian Academy of Sciences packed for the evacuation". According to this inventory, case No. 21 (248) contained Chinese manuscripts and blockprints divided into 4 groups: 1) the Kozlov Collection, Nos. 1-19, 2) unsorted texts of the same collection; 3) the Collection of S.F. Oldenburg, 4) xylographs dated 947 (3 folios). ${ }^{36}$

Soon after the Kozlov collection returned to the AM from Saratov, its processing continued as follows from the account of the AM activities in 1923: "Moreover, some convolutions and fragments in the Xia Xia language excavated and brought by P.K. Kozlov from Khara-Khoto were sorted out and arranged (see details below)". ${ }^{37}$

Members of the Department of Far Eastern Studies took part in this work, first of all Konstantin K. Flug (1893-1942). According to the acount of the AM activities in 1925 K.K. Flug "put manuscripts and blockprints from Khara-Khoto in an uniformed format system and registered 7,246 items". ${ }^{38}$ We found an apparently earlier document composed by Flug himself (it is

\footnotetext{
${ }^{34}$ Basargina E.Yu., Kirikova O.A. Khronika akademicheskoi zhizni v 1917 godu [The Chronicle of the Academy's Life in 1917]: http://www.ranar.spb.ru/rus/vystavki/id/751/. Cf. "The list of packages accepted by the authorized official V.A. Ryshkov for depositing them in the Moscow Historical Museum" (SPbB ARAS, coll. 2, inv. 1, item 38, f. 49).

${ }^{35}$ FILIPPOV 1964: 317.

${ }^{36} \mathrm{SPbB}$ ARAS, coll. 152, inv. 2, item 131, f. 30. According to a postscript to the document, the case returned to the AM on December 25, 1920.

${ }^{37} \mathrm{SPbB}$ ARAS, coll. 152, inv. 1a, item 71, f. 8. Unfortunately, we failed to find these details in any archival documents.

${ }^{38}$ SPbB ARAS, coll. 152, inv. 1a, item 80, f. 12; it was quoted in PoPOVA 2011: 238.
} 
not signed but his handwriting is recognizable enough) and entitled "An Account of the work on systematizing the Xi-Xia books brought by Kozlov from Khara-Khoto" ${ }^{39}$ It records that the texts in Tangut (6778 items) were mechanically divided into seven groups by format and concludes with the phrase: "At present, the Tangut books of the Tibetan type are being processed in a similar way". From this document we learn also that all the items processed were marked with the official AM stamp. This stamp can be still found on a number of Tangut texts but none of Tibetan texts has it. ${ }^{40}$ Therefore, it can be assumed that only an initial sorting out of texts by format could be performed at that time. ${ }^{41}$

The next mention of Tibetan materials in the context of the Khara-Khoto collection is dated 1948. According to the account of the IOS Manuscript Department, Alexander A. Dragunov (1900-1955) made some preliminary work aimed at separating Tibetan, Chinese, and Sanskrit fragments from the main Tangut part. ${ }^{42} \mathrm{We}$ do not know how many Tibetan texts were sorted out by A.A. Dragunov since he obviously left no inventories. It is possible, however, that his work facilitated the subsequent processing of the Tibetan part of the Khara-Khoto collection carried out by a Sinologist and Tibetologist Alexander S. Martynov (1933-2013) from late 1966 through 1967.

${ }^{39}$ SPbB ARAS, coll. 820, inv. 2, item 164, f. 157.

${ }^{40}$ With the exception of one item (call number XT-181) that consists of two Tibetan sheets extracted from the cover of a Tangut book to which this stamp actually belonged: the stamp indicates the language ("Xi-Xia"), format (B) and number (221).

${ }^{41}$ K.K. Flug's account is preserved in the SPbB ARAS within the personal archive of V.M. Alekseev, the eminent Russian and Soviet Sinologist, who headed the Department of Far Eastern Studies at that time. From his own document, a proposition addressed to the AM Director on June 11, 1924, we learn that quick mechanical division of books according to the format principle was imposed by the authorities of the Academy's Library since the Asiatic Museum was located in its newly construcred building from the early 1920s up to the end of the 1940s (SPbB ARAS, coll. 820, inv. 2, item 164, f. 148). It certainly was not an optimal decision for the aims of Tangut studies. The situation changed quite soon when N.A. Nevsky initiated "a systematic and deeply scholarly analysis and study of the collection of Tangut manuscripts and blockprints kept at the Asiatic Museum. He was also the first to be entrusted with the compilation of the inventory of the collection" (GORBACHEV and KYCHANOV 1963, 14).

Another document from V.M. Alekseev's personal archive shows the lack of uniformity of designations used for various parts of P.K. Kozlov's collections until the 1920s. It is a reference list compiled by A.A. Dragunov and dated April 21, 1930, with information on some Tangut and Chinese books borrowed by A.I. Ivanov in 1915-1919. The following designations are used in its eleven paragraphs: "Cozlov Tangut", "Tangutica Kozloviana", "Kozlov Tangutica", "Cozloviana” (3 times), "Kz.”, “Собр. Козлова" [“Collection of Kozlov”], "Колл. Козлова" ["Collection of Kozlov"], "Рукоп. Козлова" ["Manuscripts of Kozlov"], "Sinica Мат. Козлова" ["Sinica Materials of Kozlov"] (SPbB ARAS, coll. 820, inv. 2, item 164, f. 260).

${ }^{42}$ SPbB ARAS, coll. 152, inv. 1a, item 987, f. 7-8, 14. 
According to his account dated November 27, 1967 he numbered 63 items that "did not require preliminary conservation". ${ }^{43}$ Afterwards, he obviously added seven more texts since G.A. Leonov's thesis (defended in 1970) dealt with 70 items, officially numbered for the first time by Martynov as the Collection of Tibetan texts from Khara-Khoto. ${ }^{44}$ Clearly, it was Martynov who introduced the call numbers starting with the abbreviation XT, i.e. "XapaХото Тибет" ["Khara-Khoto Tibet"].

In the post-Soviet period the collection continued to grow. In 1995, M.I. Vorobyova-Desyatovskaya listed four groups of texts related to the Khara-Khoto collection: 1) call numbers XT-1-XT-70 from the inventory book of A.S. Martynov; 2) call numbers XT-71-XT-86 added as a result of the continuing sorting of Khara-Khoto materials; 3) about ten folios of the Prajñāpāramitā sutras extracted from the covers of Tangut books; 4) fragments marked as "Koz. 1-11". 45

All the items mentioned in nos. 2-4 of this list and some others were included in the inventory book by S.S. Sabrukova who processed the collection in 2007-2008. Finally, in 2015-2017 A.A. Sizova added to the collection 21 items (XT-159-XT-179) that had been identified as those from Khara-Khoto by A.V. Zorin during the ongoing processing of the Tibetan collection of the IOM, RAS. ${ }^{46}$

In the course of our project aimed at cataloguing the Tibetan texts from Khara-Khoto that started in 2018 we sorted out 39 items that had been apparently originated from other sources:

1) XT-73, a specimen of pala script along with some Tangut and Chinese characters, was transferred to the Tangut collection; ${ }^{47}$

\footnotetext{
${ }^{43} \mathrm{SPbB}$ ARAS, coll. 152, inv. 1a, item 1862, f. 36-37.

${ }^{44}$ Leonov noted that two texts were divided between two separate items each (XT-28 and XT-53; XT-64 and XT-67) and that XT-16 contained two different texts. Therefore, Leonov's catalogue contained data on 69 texts. In fact, XT-16 contained three fragments, and two of them were later given individual inventory nos. 71 and 72 , the call number remained the same but letters $a, b, c$ were added to differentiate the three pieces inside of it. Our own analysis has shown that all the three used to belong to one manuscript and such differentiation was not necessary.

${ }^{45}$ Vorobyova-Desyatovskaya 1995, 47. In fact there are 12 fragments (Koz. 1-12), that correspond to actual call numbers as follows: Koz. $1 \rightarrow \mathrm{XT}-116$; Koz. 2,3,4,5 $\rightarrow$ XT-113; Koz. 6.7 $\rightarrow$ XT-115; Koz. 8,9,10,11 $\rightarrow$ XT-114; Koz. $12 \rightarrow$ XT-117.

${ }^{46}$ The reader should note that the call numbers and inventory numbers of the collection are not the same and they correspond to each other as follows: XT 1-70 - inv. 1-70; XT 16/2 inv. 71; XT 16/3 - inv. 72; XT $71-$ inv. 91; XT 72-78 - inv. 73-79; XT 79-inv. 92; XT 80-90 - inv. 80-90; XT 91-158 - inv. 93-160; XT 159-161 - inv. 162-164; XT 162 inv. 161; XT 163-179 - inv. 165-181.

${ }^{47}$ In the Tangut collection identical blockprints have call number Tang. 1109.
} 
2) XT-89;90;104; 125 were transferred to the Tibetan collection, three of them being the $18^{\text {th }}$ century Kalmyk manuscripts on Russian paper and one belonging to the very first Tibetan texts acquired by the IAS in the first half of the 18th c. as evidenced by a specific little black seal with a doubleheaded eagle; ${ }^{48}$

3) XT-2; $4 ; 11 ; 12 ; 13 ; 14 ; 15 ; 17 ; 24 ; 29 ; 30 ; 31 ; 32 ; 33 ; 34 ; 35 ; 39 ; 46$; $50 ; 52 ; 56 ; 57 ; 70 ; 77 ; 80 ; 81 ; 82 ; 83 ; 84 ; 85 ; 86 ; 92 ; 97 ; 108$ - manuscripts from Dunhuang judging by paper and some paleographic features (although we are not absolutely sure in regard of some of them).

The Khara-Khoto collection contains also a number of items that, according to their paleographic features, were certainly produced after the 14th $\mathrm{c}$. which is the upper bound for the dating of Khara-Khoto objects related to the Tangut period: XT-20; 26(?); 37; 38; 40; 41; 42; 43; 45; ${ }^{49} 48 ; 49 ; 51 ; 59 ; 69$; $71 ; 79 ; 91 ; 94 ; 98 ; 132 ; 134(?)$. However, it cannot be excluded that they could be brought by Kozlov from Khara-Khoto or nearby places so we decided to leave these materials inside the collection until we find any convincing evidence that they have nothing to do with the Kozlov expedition. In the catalogue they will be presented in an appendix.

Finally, in addition to the numbered items, the repository contained a few unprocessed fragments from both Khara-Khoto and Dunhuang. As was said before, two dozens of Dunhuang pieces were officially included in the Khara-Khoto collection while one Khara-Khoto scroll, on the contrary, in the Dunhuang collection. Without doubt, the two collections were mixed up to some extent and, apparently, it took place before the World War II because several Chinese texts from Khara-Khoto turned out to be inventoried by K.K. Flug (who died in besieged Leningrad in 1942) as manuscripts from Dunhuang. ${ }^{50}$ We do not know exactly when the mixture of the two collections happened. It is very likely that initially it took place when the Kozlov and Oldenburg collections were put together in one case and sent to Saratov in a haste (the decision about the evacuation was made on September 2, 1917, and the train left Leningrad on October 10). The further moves

\footnotetext{
${ }^{48}$ These texts turned out to be added to the Khara-Khoto collection because many unprocessed materials from various sources that looked old had been obviously put together and mixed this way at a certain point in the Soviet time. S.S. Sabrukova had to interrupt her work when she noted the discrepancy of some manuscripts with Khara-Khoto specimens. The folios that raised her suspicion were transferred to the Tibetan collection and many of them, after detailed examination, were identified as those obtained by the IAS in the 18th c.

${ }^{49}$ This manuscript seems to be a fake ancient text.

${ }^{50}$ MEN'SHIKOV 1984, 6, 411.
} 
of the AM to the new building of the Academy's Library in 1925 and then, of the IOS, to the Novo-Mikhailovsky Palace in 1949-1950 were also potentially dangerous in this respect. ${ }^{51}$ The full-scale inventory of the collections from Central Asia started only in the second half of the 1950s.

In October 2018, it was decided to transfer all the newly recognized Dunhuang materials to the Dunhuang collection (Дх. Тиб. 222-255, inv. Nos. 222-255) while the scroll that previously had call number Дх. Тиб. 178 from the Dunhuang collection to the Khara-Khoto one (new call number: XT-194, inv. 196). The inventory numbers and call numbers that used to belong to these items were left vacant. A few previously unprocessed pieces were also added to the two collections (XT-180-193, inv. Nos. 182-195; Дх. Тиб. 256-265, inv. Nos. 256-265).

These changes have resulted in the following situation:

- the collection of Tibetan manuscripts from Dunhuang consists of 263 items: call numbers from Дх. Тиб. 1 to Дх. Тиб. 265, with vacant numbers 24 and 178 ;

- the collection of Tibetan texts from Khara-Khoto consists of 147 items: call numbers from XT-1 to XT-194, with 39 vacant numbers and 8 numbers merged into some others (see Appendix).

This preliminary inspection and new arrangement of two collections of ancient texts in Tibetan that are preserved in the IOM, RAS are essential for the accomplishment of our main goal, the compilation of the catalogue of Tibetan texts from Khara-Khoto and, additionally, the introduction of previously unpublished texts from Dunhuang. At the same time, the study of the archival documents allowed us to clarify some significant moments in the history of P.K. Kozlov's collection. The exact date of its transfer to the Asiatic Museum - April 20 (May 3), 1911 - the fact that it was sent to Saratov along with Oldenburg's collection in October 1917 so that parts of the two collections could be mixed up for the first time seem to be of special importance.

\footnotetext{
${ }^{51}$ Notably, an act concerning some internal transfer of the materials within the Manuscript Department (dated May 31, 1962) stated that "during the inspection of 1956 the [KharaKhoto] collection was registered among the unprocessed materials of the Dunhuang collection. The non-inventoried materials include 37 boxes and 1 pack of fragments" (SPbB ARAS, coll. 152 , inv. 1 a, item 1503 , f. 20 ).
} 


\section{Appendix}

\section{Table showing the current state of the IOM collection} of the Tibetan texts from Khara-Khoto

Legend: $\rightarrow$ moving or merging; lp — "later period"; TC — collection of Tibetan blockprints and manuscripts; Tang. - Tangut collection. Invalid call numbers are italicized.

\begin{tabular}{|c|c|}
\hline XT 1 & \\
\hline$x m 2$ & $\rightarrow$ Дх. Тиб. 222 \\
\hline XT 3 & \\
\hline$x m 4$ & $\rightarrow$ Дх. Тиб. 223 \\
\hline XT 5 & \\
\hline XT 6 & \\
\hline XT 7 & \\
\hline XT 8 & \\
\hline XT 9 & \\
\hline XT 10 & \\
\hline$x m 11$ & ] $\rightarrow$ Дх. Тиб. 224 \\
\hline$x m 12$ & $\rightarrow$ Дх. Тиб. 225 \\
\hline$x m 13$ & $\rightarrow$ Дх. Тиб. 226 \\
\hline$x m 14$ & $\rightarrow$ Дх. Тиб. 227 \\
\hline$x m 15$ & $\rightarrow$ Дх. Тиб. 228 \\
\hline XT 16 & \\
\hline$x m 17$ & $\rightarrow$ Дх. Тиб. 229 \\
\hline Xт 18 & \\
\hline ХT 19 & \\
\hline Xт 20 & lp \\
\hline XT 21 & \\
\hline XT 22 & \\
\hline XT 23 & \\
\hline$x m 24$ & $\rightarrow$ Дх. Тиб. 230 \\
\hline XT 25 & \\
\hline Xт 26 & $\operatorname{lp}$ \\
\hline XT 27 & \\
\hline XT 28 & \\
\hline$x m 29$ & $\rightarrow$ Дх. Тиб. 231 \\
\hline$x m 30$ & $\rightarrow$ Дх. Тиб. 232 \\
\hline$x m 31$ & $\rightarrow$ Дх. Тиб. 233 \\
\hline$x m 32$ & $\rightarrow$ Дх. Тиб. 234 \\
\hline$x m 33$ & $\rightarrow$ Дх. Тиб. 235 \\
\hline$x m 34$ & $\rightarrow$ Дх. Тиб. 236 \\
\hline$x m 35$ & $\rightarrow$ Дх. Тиб. 237 \\
\hline XT 36 & \\
\hline Xт 37 & lp \\
\hline XT 38 & lp \\
\hline$x m 39$ & $\rightarrow$ Дх. Тиб. 238 \\
\hline ХT 40 & $\operatorname{lp}$ \\
\hline XT 41 & lp \\
\hline XT 42 & lp \\
\hline XT 43 & $\mathrm{lp}$ \\
\hline XT 44 & \\
\hline XT 45 & lp \\
\hline$x m 46$ & $\rightarrow$ Дх. Тиб. 239 \\
\hline XT 47 & \\
\hline XT 48 & lp \\
\hline XT 49 & lp \\
\hline$x m 50$ & $\rightarrow$ Дх. Тиб. 240 \\
\hline
\end{tabular}

\begin{tabular}{|c|c|}
\hline XT 51 & \multirow{5}{*}{$\stackrel{\operatorname{lp}}{\rightarrow}$ Дх. Тиб. 241} \\
\hline$x m 52$ & \\
\hline XT 53 & \\
\hline Xт 54 & \\
\hline XT 55 & \\
\hline$x m 56$ & \multirow{2}{*}{$\begin{array}{l}\rightarrow \text { Дх. Тиб. } 242 \\
\rightarrow \text { Дх. Тиб. } 243\end{array}$} \\
\hline$x m 57$ & \\
\hline ХT 58 & \multirow{6}{*}{ lp } \\
\hline Хт 59 & \\
\hline XT 60 & \\
\hline XT 61 & \\
\hline Хт 62 & \\
\hline $\begin{array}{l}\text { XT } 63 \\
\end{array}$ & \\
\hline$x m 64$ & \multirow[t]{4}{*}{$\rightarrow$ хт 67} \\
\hline \begin{tabular}{|l|} 
XT 65 \\
\end{tabular} & \\
\hline ХT 66 & \\
\hline Xт 67 & \\
\hline$x m 68$ & \multirow{4}{*}{$\begin{array}{l}\rightarrow \text { хт } 63 \\
\operatorname{lp} \\
\operatorname{lp}\end{array}$} \\
\hline Хт 69 & \\
\hline$x m 70$ & \\
\hline \begin{tabular}{|l|} 
XT 71 \\
\end{tabular} & \\
\hline Xт 72 & \multirow{5}{*}{$\rightarrow$ Tang. } \\
\hline$x m 73$ & \\
\hline Xт 74 & \\
\hline XT 75 & \\
\hline \begin{tabular}{|l|} 
XT 76 \\
\end{tabular} & \\
\hline$x m 77$ & \multirow[t]{2}{*}{$\rightarrow$ Дх. Тиб. 245} \\
\hline Xт 78 & \\
\hline ХT 79 & \multirow{8}{*}{$\begin{array}{l}\operatorname{lp} \\
\rightarrow \text { Дх. Тиб. } 246 \\
\rightarrow \text { Дх. Тиб. } 247 \\
\rightarrow \text { Дх. Тиб. } 248 \\
\rightarrow \text { Дх. Тиб. } 249 \\
\rightarrow \text { Дх. Тиб. } 250 \\
\rightarrow \text { Дх. Тиб. } 251 \\
\rightarrow \text { Дх. Тиб. } 252\end{array}$} \\
\hline$x m 80$ & \\
\hline$x m 81$ & \\
\hline$x m 82$ & \\
\hline$x m 83$ & \\
\hline$x m 84$ & \\
\hline$x m 85$ & \\
\hline$x m 86$ & \\
\hline Xт 87 & \multirow{7}{*}{$\begin{array}{l}\rightarrow \text { ТС } \\
\rightarrow \text { ТС } \\
\operatorname{lp} \\
\rightarrow \text { Дх. Тиб. } 253\end{array}$} \\
\hline ХT 88 & \\
\hline$x m 89$ & \\
\hline$x m 90$ & \\
\hline XT 91 & \\
\hline$x m 92$ & \\
\hline XT 93 & \\
\hline XT 94 & \multirow[t]{3}{*}{$\operatorname{lp}$} \\
\hline XT 95 & \\
\hline XT 96 & \\
\hline$x m 97$ & \multirow{4}{*}{$\rightarrow$ Дх. Тиб. 254} \\
\hline XT 98 & \\
\hline XT 99 & \\
\hline XT 100 & \\
\hline
\end{tabular}

\begin{tabular}{|c|c|c|c|}
\hline & \multirow{8}{*}{$\rightarrow \mathrm{TC}$} & & \\
\hline Xт 101 & & XT 151 & \\
\hline XT 102 & & XT 152 & \\
\hline XT 103 & & XT 153 & \\
\hline$x m 104$ & & \begin{tabular}{|l|} 
XT 154 \\
\end{tabular} & \\
\hline XT 105 & & XT 155 & \\
\hline XT 106 & & Хт 156 & \\
\hline XT 107 & & XT 157 & \\
\hline$x m 108$ & \multirow[t]{17}{*}{$\rightarrow$ Дх. Тиб. 255} & XT 158 & \\
\hline Xт 109 & & $x m 159$ & $\rightarrow \mathrm{xT} 126$ \\
\hline XT 110 & & \begin{tabular}{|l|} 
XT 160 \\
\end{tabular} & \\
\hline XT 111 & & XT 161 & \\
\hline XT 112 & & Хт 162 & \\
\hline XT 113 & & $x m 163$ & $\rightarrow$ хт 16 \\
\hline XT 114 & & $x m 164$ & $\rightarrow \mathrm{xT} 16$ \\
\hline XT 115 & & ХT 165 & \\
\hline XT 116 & & Xт 166 & \\
\hline XT 117 & & ХT 167 & \\
\hline XT 118 & & ХT 168 & \\
\hline XT 119 & & \begin{tabular}{|l|} 
Xт 169 \\
\end{tabular} & \\
\hline XT 120 & & Xт 170 & \\
\hline XT 121 & & \begin{tabular}{|l|} 
XT 171 \\
\end{tabular} & \\
\hline XT 122 & & Xт 172 & \\
\hline XT 123 & & Хт 173 & \\
\hline XT 124 & & Xт 174 & \\
\hline$x m 125$ & \multirow[t]{7}{*}{$\rightarrow \mathrm{TC}$} & Xт 175 & \\
\hline XT 126 & & $x m 176$ & $\rightarrow \mathrm{xT} 94$ \\
\hline XT 127 & & XT 177 & \\
\hline XT 128 & & Xт 178 & \\
\hline XT 129 & & Хт 179 & \\
\hline XT 130 & & Xт 180 & \\
\hline XT 131 & & Xт 181 & \\
\hline XT 132 & \multirow[t]{8}{*}{$\operatorname{lp}$} & XT 182 & \\
\hline XT 133 & & Xт 183 & \\
\hline XT 134 & & XT 184 & \\
\hline XT 135 & & XT 185 & \\
\hline XT 136 & & Xт 186 & \\
\hline XT 137 & & Xт 187 & \\
\hline XT 138 & & Xт 188 & \\
\hline Xт 139 & & $x m 189$ & $\rightarrow \mathrm{XT} 126$ \\
\hline$x m 140$ & \multirow[t]{5}{*}{$\rightarrow$ ХT 94} & XT 190 & \\
\hline XT 141 & & Xт 191 & \\
\hline XT 142 & & \begin{tabular}{|l|} 
XT 192 \\
\end{tabular} & \\
\hline XT 143 & & XT 193 & \\
\hline XT 144 & & Xт 194 & Ł Дх. Тиб. 178 \\
\hline
\end{tabular}

XT 145

XT 146

XT 147

XT 148

XT 149

XT 150 


\author{
Abbreviations \\ AM: Asiatic Museum \\ ARME: Archive of the Russian Museum of Ethnography \\ coll.: collection (in references to archival materials stands for фонд) \\ EDRM: Ethnographic Department of the Russian Museum \\ inv.: inventory (in references to archival materials stands for $о$ олисb) \\ IOM, RAS: Institute of Oriental Manuscript of the Russian Academy of Sciences \\ IRGS: Imperial Russian Geographical Society \\ RGS: Russian Geographical Society \\ SPbB ARAS: St. Petersburg Branch of the Archive of the Russian Academy of Sciences
}

\title{
References
}

Bogdanov K.M. 2010: "Tibetskie knigi iz Khara-Khoto (kollektsiia P.K. Kozlova)" [Tibetan books from Khara-Khoto (P.K. Kozlov Collection)]. Pis'mennye pamiatniki Vostoka, 2010, 2(13), 263-271.

BULLETIN 1911: "Istoriko-filologicheskoe otdelenie. Zasedanie 30 marta 1911 goda" [Historico-Philological Department. The meeting held on 30 March 1911]. Izvestiia Imperatorskoi Akademii Nauk [The Bulletin of the Imperial Academy of Sciences], ser. VI, vol. V, no. 9, 738-739.

DuAN Yuquan 段玉泉 2010: “Xixia zang chuan “Zun sheng jing” de xia han cang dui kan yanjiu” 西夏藏传《尊胜经》的夏汉藏对勘研究 (A Comparison research on Sarvatathāgatoṣnīṣavijaya in its Tangut, Chinese and Tibetan versions). Xixia xue 西夏学 (Xixia Studies), 5, 29-37.

ECANG HEISHUICHENG WENXIAN 1996-2018: Ecang Heishuicheng wenxian 俄藏黑水城文献 $=$ Heishuicheng manuscripts collected in Russia. Shanghai: Shanghai guji chubanshe 上海 古籍出版社 $=$ Shanghai Chinese Classics Publishing House, (vols. 1-6 for Chinese, 7-27 for Tangut texts).

FILIPPOV M.S. 1964: Istoriia Biblioteki Akademii nauk SSSR. 1714-1964 [The history of the library of the USSR Academy of Sciences. 1714-1964]. Authors: S.P. Luppov, A.I. Kopanev, M.V. Kukushkina, P.V. Sokolov, V.N. Voronov, V.Ia. Khvatov. Ed. by M.S. Filippov. Moscow; Leningrad: Nauka.

GorbaCHEVA Z.I. and KyCHANOV E.I. 1963: Tangutskie rukopisi i ksilografy. Spisok otozhdestvlennykh i opredelennykh tangutskikh rukopisei i ksilografov kollektsii Instituta narodov Azii AN SSSR [Tangut manuscripts and xylographs. The list of identified and classified Tangut nanuscripts and xylographs from the collection of the Institute of the peoples of Asia, the USSR Academy of Sciences]. Moscow: Izdatel'stvo vostochnoi literatury.

IUSUPOVA T.I. 2008: Mongolo-Sychuan'skaia ekspeditsiia P.K. Kozlova (1907-1909) i otkrytie Khara-Khoto [P.K. Kozlov's Mongolia and Sichuan expedition (1907-1909): the discovery of Khara-Khoto]. Rossiiskie ekspeditsii v Tsentral'nuiu Aziiu v kontse XIX nachale XX veka [Russian expeditions to Central Asia at the Turn of the 20th century. Ed. by I.F. Popova]. St. Petersburg: Slaviia, 112-129.

IUSUPOVA T.I. 2012: "Obshchee i chastnoe znachenie arkheologicheskikh otkrytii v KharaKhoto" [The general and particular significance of the archaeological discoveries at Khara- 
Khoto]. Tanguty v Tsentral'noi Azii: sbornik statei v chest' 80-letiia prof. E.I. Kychanova [Tanguts in Central Asia: a collection of articles marking the 80th anniversary of prof. E.I. Kychanov]. Sost. i otv. red. I.F. Popova [Ed. by I.F. Popova]. Moscow: Vostochnaia literatura, 481-489.

KAZIN V.N. 1961: "K istorii Khara-Khoto [On the history of Khara-Khoto]". Trudy Gosudarstvennogo Ermitazha [Transactions of the State Hermitage Museum], vol. V. Leningrad: Izdatel'stvo Gosudarstvennogo Ermitazha (Kul'tura i iskusstvo narodov Vostoka, 6), 273-285.

Kozlov P.K. 1923: Mongoliia i Amdo i mertvyi gorod Khara-Khoto. Ekspeditsiia IRGO v Nagornoi Azii 1907-1909 [Mongolia and Amdo and the dead city of Khara-Khoto. The expedition of the Imperial Russian Geographical Society to High Asia 1907-1909]. Moscow; Petrograd: Gosizdat.

Kozlov P.K. 1963: Russkii puteshestvennik v Tsentral'noi Azii. Izbrannye trudy. K stoletiiu so dnia rozhdeniia (1863-1963) [The Russian traveller in Central Asia. Selected works. dedicated to P.K. Kozlov's Centenary (1863-1963)]. Moscow: Izdatel'stvo AN SSSR.

KozLov P.K. 2015: Dnevniki Mongolo-Sychuan'skoi ekspeditsii, 1907-1909 [The diaries of the Mongolia-Sichuan expedition, 1907-1909]. Compiled and ed. by T.I. Iusupova, compiled by T.Iu. Gnatiuk; Editor-in-chief A.I. Andreev. St. Petersburg: NestorIstoriia.

Kozlov V.P. 1948: "Nauchnoe znachenie arkheologicheskikh nakhodok P.K. Kozlova" [The acientific aignificance of P.K. Kozlov's archaeological findings]. In: Kozlov P.K. Mongoliia i Amdo i mertvyi gorod Khara-khoto [Mongolia and Amdo and the dead city of Khara-Khoto]. Moscow: OGIZ Gosudarstvennoe izdatel'stvo geograficheskoi literatury, 9-18.

KYCHANOV E.I. 1999: Katalog tangutskikh buddiiskikh pamiatnikov Instituta vostokovedeniia Rossiiskoi Akademii Nauk [The catalogue of Tangut Buddhist texts kept at the Institute of Oriental Studies, the Russian Academy of Sciences]. Compiled by E.I. Kychanov; Introductory Article by T. Nishida; Ed. by Sh. Arakawa; Editor-in-chief T. Nishida. [Kyōto:] University of Kyōto.

KyCHANOv E.I. 2008: "Tangutskii fond Instituta vostochnykh rukopisei Rossiiskoi Akademii nauk i ego izuchenie" [The Tangut collection of the Institute of Oriental Manuscripts: history and study]. In: Rossiiskie ekspeditsii v Tsentral'nuiu Aziiu v kontse XIX - nachale $X X$ veka [Russian expeditions to Central Asia at the turn of the 20th century]. Ed. by I.F. Popova. St. Petersburg: Slaviia, 130-147.

LEONOV G.A. 1970: A Description of the Tibetan manuscripts and block prints of the Kharakhoro Collection of the Institute of Oriental Studies. A thesis of a 5th year student at the Faculty of Oriental Studies, Leningrad State University, the group of Tibetan Philology, G.A. Leonov [Diplom studenta 5 kursa Vostochnogo fakul'teta LGU otd. tibetskoi filologii G.A. Leonova. Opisanie tibetskikh rukopisei i ksilografov Khara-khotosskogo fonda Instituta vostokovedeniia]. Leningrad [1970]. The typescript is kept at the archives of the Department of manuscripts and documents of the IOM, RAS. Access number Apx. 107.

LIN Ying-chin 林英津 2011: “Xixia yuyi “Zun sheng jing” shiwen” 西夏语译 《尊胜经 (Ușṇiṣa Vijaya Dhāraṇī)》 釋文 (Tangut version of Ușnị̄ṣa Vijaya Dhāraṇ̂”). Xixia xue 西 夏学 (Xixia Studies) 8, 23-61. 
Men'shiKov L.N. 1984: Opisanie kitaiskoi chasti kollektsii iz Khara-Khoto (fond P.K. Kozlova) [The description of the Chinese part of the Khara-Khoto collection (P.K. Kozlov's Fund)]. Supplemets Compiled by L.I. Chuguevskii. Moscow: Nauka, Glavnaia redaktsiia vostochnoi literatury.

Popova I.F. 2011: Flug K.K. "Chao Gun-u i ego bibliografiia "Tsziun'-chzhai du shu chzhi” [Chao Gong-wu and his bibliography "Zun zhai du shu zhi"]. Introduction and Publication by I.F. Popova. Trudy vostokovedov v gody blokady Leningrada (1941-1944) [Works of the Orientalists during the siege of Leningrad (1941-1944)]. Moscow: Vostochnaia literatura, 236-285.

SHEN Weirong 2010: "Reconstructing the history of Buddhism in Central Eurasia (11th14th centuries): An Interdisciplinary and Multilingual Approach to the Khara Khoto Texts". Edition, éditions: l'écrit au Tibet, évolution et devenir. München: Indus Verlag, $337-362$.

SHI Jinbo 史金波 2005: “Zuizao de zangwen mukeben kaolüe” 最早的藏文木刻本考略 (Brief overview of the Earliest Tibetan blockprints). Zhongguo zangxue 中国藏学 (Chinese Tibetology), no. 4 (72), 73-77.

SHIRAI Satoko 白井聡子 2004: “Roshia shozō Chibetto-go shūchinhon ni tsuite” ロシア所蔵 チベット語袖珍本について (1) [A Tibetan pocketbook in a Russian manuscript collection (1)]. Kyōtodaigaku gengo-gaku kenkyū 京都大学言語学研究 [Kyoto University Linguistic Research] 23, 167-190.

TAKEUCHI Tsuguhito 1995: "Kh. Tib. (Kozlov 4): Contracts for the Borrowing of Barley". Manuscripta Orientalia, vol. 1, no. 1, 49-52.

TAKeuCHI Tsuguhito, IUCHI Maho 2016: Tibetan Texts from Khara-Khoto in the Stein Collection of the British Library. Tokyo: the Toyo Bunko (Studia Tibetica, no. 48) (Studies in Old Tibetan Texts from Central Asia, vol. 2).

TALA et al. 2013: Zhongguo cang Heishuicheng minzu wenzi wenxian 中國藏黑水城民族字 文獻 [Documents in Minority writings from Khara-khoto collected in China]. Tala, Du Jianlu, Gao Guoxiang zhubian 塔垃, 杜建录, 高国祥主编 [Ed. by Tala, Du Jianlu and Gao Guoxiang]. Tianjin 天津: Tianjin guji chubanshe 天津古籍出版社.

Vorobyova-Desyatovskaya, Margarita 1995: "Tibetan Manuscripts of the 8-11th centuries A.D. in the Manuscript Collection of the St. Petersburg Branch of the Institute of Oriental Studies". Manuscripta Orientalia, vol. 1, no. 1, 46-48.

Yoshida Jun'ichi, ChimeddonJI 吉田順一、チメドドルジ 2008: Harahoto shutsudo mongoru bunsho-no kenkyū ハラホト出土モンゴル文書の研究 = Study on the Mongolian documents found at Qaraqota. Yoshida Jun'ichi, Chimedodoruji hen 吉田順一、 チメドドルジ編 [Ed. by Yoshida Jun'ichi, Chimeddorji]. Tōkyō 東京: Yūzankaku 雄 山閣.

ZoRIN A.V. 2015: Buddiiskie ritual'nye teksty: po tibetskoi rukopisi XIII v. [Buddhist ritual texts as represented in a Tibetan manuscript from the 12th Century]. Faksimile rukopisi; transliteratsiia A.V. Zorina pri uchastii S.S. Sabrukovoi; per. s tibetskogo, vstupit. stat'ia, primech. i prilozhenie A.V. Zorina [Facsimile ed., transliteration by A.V. Zorin and S.S. Sabrukova; tr. from Tibetan, Introduction, Notes and Appendix by A.V. Zorin]. Moscow: Nauka-Vostochnaia literatura (Pamiatniki pis'mennosti Vostoka, CXLVI). 